\title{
Auxiliary Subunit GSG1L Acts to Suppress Calcium- Permeable AMPA Receptor Function
}

\author{
ㄷThomas P. McGee, Cécile Bats, Mark Farrant, and Stuart G. Cull-Candy \\ Department of Neuroscience, Physiology, and Pharmacology, University College London, London WC1E 6BT, United Kingdom
}

\begin{abstract}
AMPA-type glutamate receptors are ligand-gated cation channels responsible for a majority of the fast excitatory synaptic transmission in the brain. Their behavior and calcium permeability depends critically on their subunit composition and the identity of associated auxiliary proteins. Calcium-permeable AMPA receptors (CP-AMPARs) contribute to various forms of synaptic plasticity, and their dysfunction underlies a number of serious neurological conditions. For CP-AMPARs, the prototypical transmembrane AMPAR regulatory protein stargazin, which acts as an auxiliary subunit, enhances receptor function by increasing single-channel conductance, slowing channel gating, increasing calcium permeability, and relieving the voltage-dependent block by endogenous intracellular polyamines. We find that, in contrast, GSG1L, a transmembrane auxiliary protein identified recently as being part of the AMPAR proteome, acts to reduce the weighted mean single-channel conductance and calcium permeability of recombinant CP-AMPARs, while increasing polyaminedependent rectification. To examine the effects of GSG1L on native AMPARs, we manipulated its expression in cerebellar and hippocampal neurons. Transfection of GSG1L into mouse cultured cerebellar stellate cells that lack this protein increased the inward rectification of mEPSCs. Conversely, shRNA-mediated knockdown of endogenous GSG1L in rat cultured hippocampal pyramidal neurons led to an increase in mEPSC amplitude and in the underlying weighted mean single-channel conductance, revealing that GSG1L acts to suppress current flow through native CP-AMPARs. Thus, our data suggest that GSG1L extends the functional repertoire of AMPAR auxiliary subunits, which can act not only to enhance but also diminish current flow through their associated AMPARs.
\end{abstract}

Key words: auxiliary AMPAR subunits; calcium-permeable AMPARs; glutamatergic synapses; GSG1L; polyamine block; single channels

\section{Significance Statement}

Calcium-permeable AMPA receptors (CP-AMPARs) are an important group of receptors for the neurotransmitter glutamate. These receptors contribute to various forms of synaptic plasticity, and alterations in their expression or regulation are also seen in a number of serious neurological conditions, including stroke, motor neuron disease, and cocaine addiction. Several groups of auxiliary transmembrane proteins have been described that enhance the function and cell-surface expression of AMPARs. We now report that the recently identified auxiliary protein GSG1L decreases weighted mean channel conductance and calcium permeability of CP-AMPARs while increasing polyamine-dependent rectification by diminishing outward current. Our experiments reveal that GSG1L is an auxiliary subunit that can markedly suppress CP-AMPAR function, in both recombinant systems and central neurons.

\section{Introduction}

Fast excitatory signaling in the mammalian brain relies mainly on AMPA receptors (AMPARs) that mediate rapid point-to-point transmission. These receptors also promote synapse formation and development and are themselves subject to various activitydependent modifications. Thus, they represent a central element

\footnotetext{
Received June 4, 2015; revised 0ct. 28, 2015; accepted Nov. 5, 2015.

Author contributions: T.P.M., C.B., M.F., and S.G.C.-C. designed research; T.P.M. and C.B. performed research; T.P.M., C.B., and M.F. analyzed data; T.P.M., C.B., M.F., and S.G.C.-C. wrote the paper.

This work was supported by Medical Research Council Grants MR/J002976/1 (S.G.C.-C. and M.F.) and MR/ J012998/1 (M.F. and S.G.C.-C.) and Wellcome Trust Grant 086185/Z/08/Z (S.G.C.-C. and M.F.). We are grateful to Bernd Fakler for providing GSG1L and for discussion and to laboratory members for valuable help.
}

in the processes of synaptic plasticity, learning, and memory (Newpher and Ehlers, 2008; Kessels and Malinow, 2009). AMPARs are homo- and hetero-tetramers assembled from combina-

\footnotetext{
The authors declare no competing financial interests.

This article is freely available online through the J Neurosci Author Open Choice option.

Correspondence should be addressed to either Stuart G. Cull-Candy or Mark Farrant, Department of Neuroscience, Physiology, and Pharmacology, University College London, Gower Street, London WC1E 6BT, UK, E-mail: s.cull-candy@ucl.ac.uk orm.farrant@ucl.ac.uk.

DOI:10.1523/JNEUROSCI.2152-15.2015 Copyright $\odot 2015$ McGee et al.

This is an Open Access article distributed under the terms of the Creative Commons Attribution License Creative Commons Attribution 4.0 International, which permits unrestricted use, distribution and reproduction in any medium provided that the original work is properly attributed.
} 
tions of the pore-forming subunits GluA1-GluA4 (Traynelis et al., 2010). Although a majority of central AMPARs contain the GluA2 subunit, those lacking GluA2 constitute an important subtype and endow central synapses with distinct functional characteristics. Notably, the absence of GluA2 renders AMPARs permeable to calcium; these receptors also exhibit a high singlechannel conductance and sensitivity to block by endogenous intracellular polyamines, resulting in inwardly rectifying EPSCs. The activity-dependent regulation of calcium-permeable AMPARs (CP-AMPARs) is known to underlie various forms of synaptic plasticity (Liu and Cull-Candy, 2000; Isaac et al., 2007; Clem and Huganir, 2010; Traynelis et al., 2010; Szabo et al., 2012). Furthermore, the dysfunction of CP-AMPARs contributes to deleterious neurological processes, including cell damage after stroke and postsynaptic changes associated with drug abuse (Cull-Candy et al., 2006; Liu and Zukin, 2007; Bellone and Lüscher, 2012).

Auxiliary subunits of the stargazin (transmembrane AMPAR regulatory protein; TARP) and cornichon families enhance synaptic transmission by promoting AMPAR function and forward trafficking (Jackson and Nicoll, 2011; Haering et al., 2014; Constals et al., 2015). For CP-AMPARs, these auxiliary subunits approximately double the average single-channel conductance, slow desensitization and deactivation, and enhance calcium permeability (Tomita et al., 2005; Kott et al., 2009; Soto et al., 2009, 2014; Coombs et al., 2012). They also attenuate intracellular polyamine block across all voltages, most obviously at depolarized potentials (Soto et al., 2007, 2014). The overall effect of these various modifications is to increase the size of the synaptic current and prolong its time course. Given that the conductance of CP-AMPARs is at least twice that of their GluA2-containing counterparts (Swanson et al., 1997; Soto et al., 2009; Coombs et al., 2012), the modulation of CP-AMPARs by auxiliary subunits results in substantial additional charge transfer during synaptic transmission.

GSG1L has been identified recently as an AMPAR auxiliary subunit with some structural similarity to TARPs (Schwenk et al., 2012, 2014; Shanks et al., 2012). Postembedding immunogold electron microscopy has shown that this protein is localized together with GluA2- or GluA4-containing AMPARs in dendritic spines of hippocampal pyramidal neurons, suggesting a possible role in synaptic transmission (Schwenk et al., 2012). Although there was previously no direct evidence that it influences EPSC properties, GSG1L has been shown to resemble TARPs in moderately slowing both deactivation and desensitization of recombinant AMPARs, while increasing the surface expression of GluA2 (Schwenk et al., 2012, 2014; Shanks et al., 2012). However, unlike the TARPs, GSG1L is known to slow AMPAR recovery from desensitization (Schwenk et al., 2012; Shanks et al., 2012), raising the possibility that other differences may exist between GSG1L and previously investigated auxiliary AMPAR subunits.

Here, we find that GSG1L contrasts markedly with other auxiliary AMPAR subunits so far described in decreasing the mean single-channel conductance and calcium permeability of GluA2lacking AMPARs, while greatly suppressing outward current flow in the presence of intracellular polyamines. Consistent with this, transfection of cerebellar stellate cells with GSG1L increased inward rectification of synaptic CP-AMPARs. Moreover, shorthairpin RNA (shRNA)-mediated knockdown of GSG1L in hippocampal neurons accelerated EPSC decay and increased synaptic single-channel conductance, demonstrating that GSG1L can contribute to the functional regulation of synaptic CPAMPARs in neurons.

\section{Materials and Methods}

tsA201 cell culture. Cells were maintained as described previously (Soto et al., 2007) and transfected using Lipofectamine 2000 (Invitrogen). Rat AMPAR subunits (flip isoforms) were transfected either alone or with rat GSG1L. After 4-6 h transfection, cells were washed with PBS, and the medium was replaced. Some transfected cells were maintained in the presence of $50 \mu \mathrm{M}$ NBQX to limit cytotoxic effects. Electrophysiological recordings were made 24-48 h later. AMPAR subunit cDNAs were a gift from S. Heinemann (Salk Institute, La Jolla, CA) and P. Seeburg (Max Planck Institute, Heidelberg, Germany). GSG1L (pcDNA3.1 vector) was courtesy of B. Fakler (University Freiburg, Freiburg, Germany). AMPARs were subcloned into the pIRES2-GFP vector and GFP used to identify transfected cells. GSG1L was transfected in excess of AMPAR subunits (2:1) to ensure coassembly. Tandem constructs of GSG1L and GluA1 or GluA2(Q) were made by directly linking the $\mathrm{N}$ terminus of GSG1L to the C-terminal tail of the GluA subunit, incorporating a 9 aa linker (GluA-GGGGGEFAT-GSG1L; Soto et al., 2014).

Fast agonist application to excised patches. We recorded macroscopic currents at $23-26^{\circ} \mathrm{C}$ from outside-out patches using an Axopatch $200 \mathrm{~A}$ amplifier, as described previously (Soto et al., 2007). Records were lowpass filtered at $5 \mathrm{kHz}$ and digitized at $20 \mathrm{kHz}$ using WINWCP software (John Dempster, University of Strathclyde, Glasgow, UK) and analyzed using Igor Pro 6.35 (WaveMetrics) with NeuroMatic 2.8v (http://www. neuromatic.thinkrandom.com/). Pipettes were pulled from thick-walled borosilicate glass ( $1.5 \mathrm{~mm}$ outer diameter, $0.86 \mathrm{~mm}$ inner diameter; Harvard Apparatus), coated with Sylgard resin (Dow Corning 184), and fire polished to a final resistance of $\sim 4-8 \mathrm{M} \Omega$. The external solution contained the following (in mM): $145 \mathrm{NaCl}, 2.5 \mathrm{KCl}, 1 \mathrm{CaCl}_{2}, 1 \mathrm{MgCl}_{2}, 10$ glucose, and 10 HEPES buffer, $\mathrm{pH} 7.3$ with $\mathrm{NaOH}$. Rapid application of glutamate $(10 \mathrm{~mm})$ and, when indicated, cyclothiazide (CTZ; $50 \mu \mathrm{M}$; Tocris Bioscience), was achieved by piezoelectric translation of a thetabarrel application tool. The internal (pipette) solution contained the following (in mM): $145 \mathrm{CsCl}, 2.5 \mathrm{NaCl}, 1$ Cs-EGTA, 4 Mg-ATP, 10 HEPES, pH 7.3 with $\mathrm{CsOH}$, and 0.1 spermine tetrahydrochloride (Tocris Bioscience). In some recordings, spermine was omitted and endogenous polyamines were chelated by adding $20 \mathrm{mM} \mathrm{Na}_{2} \mathrm{ATP}$ to the intracellular solution (Watanabe et al., 1991). To extract channel properties from macroscopic responses, we used nonstationary fluctuation analysis (NSFA) routines written in Igor Pro, as described previously (Soto et al., 2007). The weighted mean single-channel current (i) and the total number of channels $(N)$ were determined by plotting the ensemble variance $\left(\sigma^{2}\right)$ against mean current $(\bar{I})$ and fitting with the following equation:

$$
\sigma^{2}=i \bar{I}-\bar{I}^{2} / N+\sigma_{\mathrm{B}}^{2} .
$$

Channel openings in the tail of macroscopic patch currents (filtered at 2 $\mathrm{kHz}$ ) were also analyzed using $\mathrm{QuB}$ (version 2.0.0.7; http://www.qub. buffalo.edu/). Clear single-channel events (lasting longer than $2 \mathrm{~ms}$ ) were selected by eye and preprocessed with piecewise linear baseline correction. For each selected record, an all-point amplitude histogram was generated and fitted with two Gaussians to determine the amplitude of the single-channel current. In each case, the mean amplitude was at least 2.5 times the SD of the background noise (0.1-1 pA). On average, 53 channel events (range, 28-145) were measured from each patch. Current-voltage $(I-V)$ relationships were examined from -80 to $+100 \mathrm{mV}$, and rectification index $\left(\mathrm{RI}_{+80 /-80}\right)$ values were calculated as the ratio of the peak current at 80 and $-80 \mathrm{mV}$. For philanthotoxin- $433(\mathrm{PhTx}-433$; Sigma) block experiments, patches were exposed to glutamate (1 mM) and CTZ $(50 \mu \mathrm{M})$ before being switched rapidly to a solution with glutamate, CTZ, and PhTX-433.

Measurement of calcium permeability. This was performed as described previously (Soto et al., 2007). Ramps from -80 to $+80 \mathrm{mV}$ were applied in "low" and "high" $\mathrm{Ca}^{2+}$ solutions (in $\mathrm{mm}$ ): low $\mathrm{Ca}^{2+}, 145 \mathrm{NaCl}, 2.5$ $\mathrm{KCl}, 1 \mathrm{CaCl}_{2}, 1 \mathrm{MgCl}_{2}$, and 10 HEPES, pH 7.3 with $\mathrm{NaOH}$; high $\mathrm{Ca}^{2+}, 30$ $\mathrm{CaCl}_{2}, 110 \mathrm{~N}$-methyl-D-glucamine, 5 HEPES, and 50 sucrose, $\mathrm{pH} 7.3$ with $\mathrm{HCl}$. Control ramps were recorded in each solution and then in the same solutions containing $10 \mathrm{~mm}$ glutamate and $50 \mu \mathrm{M} \mathrm{CTZ}$. The control $I-V$ relationships were subtracted from those obtained in agonist. In these experiments, the pipette solution contained either $100 \mu \mathrm{M}$ or no 
added spermine. As no differences in the reversal potentials were observed and the data were pooled. The relative $\mathrm{Ca}^{2+}$ permeability, $P_{\mathrm{Ca}} / P_{\mathrm{Na}}$, was determined from the reversal potentials in low and high $\mathrm{Ca}^{2+}$ extracellular solutions using the following equation:

$$
P_{\mathrm{Ca}} / P_{\mathrm{Na}}=\frac{a_{\mathrm{Na}}}{4 a_{\mathrm{Ca}}}\left(\exp \frac{\left(2 V_{\mathrm{rev} \mathrm{Ca}}-V_{\mathrm{rev} \mathrm{Na}}\right) F}{R T}+\exp \frac{\left(V_{\mathrm{rev} \mathrm{Ca}}-V_{\text {rev Na }}\right) F}{R T}\right),
$$

where $a_{\mathrm{Na}}$ and $a_{\mathrm{Ca}}$ represent the activities of $\mathrm{Na}^{+}$and $\mathrm{Ca}^{2+}$ in the extracellular solutions (108.7 and 16.5, calculated from activity coefficients of 0.75 and 0.55 , respectively; Geiger et al., 1995), and $R, T$, and $F$ have their conventional meanings.

Cerebellar cultures. Primary dissociated cultures were prepared from male and female postnatal day 5 (P5) to P6 C57BL/6 mice (Bats et al., 2012). All procedures for the care and treatment of mice were in accordance with the Animals (Scientific Procedures) Act 1986. After dissociation, the cells in suspension were transfected with GFP or GSG1L:IRES: GFP plasmids by electroporation using the Amaxa nucleofection system and Amaxa mouse neuron nucleofector kit (Lonza). Neurons were then plated on poly-L-lysine-coated glass coverslips and grown in a humidified $5 \% \mathrm{CO}_{2}$-containing atmosphere at $37^{\circ} \mathrm{C}$ in Basal Medium Eagle (Gibco) supplemented with $\mathrm{KCl}$ (25 mm final concentration), 10\% fetal bovine serum (v/v; Gibco), $20 \mu \mathrm{g} / \mathrm{ml}$ gentamicin, and $2 \mathrm{~mm}$ L-glutamine for $3 \mathrm{~d}$. Unlike our previous study (Bats et al., 2012), after $3 \mathrm{~d}$ in vitro we replaced the growing medium with a serum-free low-potassium medium to prevent glial cell proliferation and promote synaptic activity [Eagle's Minimum Essential Medium (Gibco) supplemented with $5 \mathrm{mg} / \mathrm{ml} \mathrm{glu-}$ cose, $0.1 \mathrm{mg} / \mathrm{ml}$ transferrin, $0.025 \mathrm{mg} / \mathrm{ml}$ insulin, $2 \mathrm{~mm}$ glutamine, and 20 $\mu \mathrm{g} / \mathrm{ml}$ gentamicin]. Recordings were made from stellate cells after 8-11 $\mathrm{d}$ in vitro.

Hippocampal cultures. Dissociated hippocampal neurons were prepared from P0-P1 female Sprague Dawley rat pups and isolated as described previously (Beaudoin et al., 2012). Briefly, hippocampi were dissected and then digested with warm papain solution for $1 \mathrm{~h}$ at $37^{\circ} \mathrm{C}[20$ $\mathrm{U} / \mathrm{ml}$ papain, $0.5 \mathrm{~mm}$ EDTA, and $1 \mathrm{~mm}$ L-cysteine (Worthington Biochemical) in Earle's balanced salt solution (EBSS; Sigma)]. Tissue digest was halted with albumin-ovomucoid inhibitor solution (2.7 $\mathrm{ml}$ of EBSS plus $300 \mu \mathrm{l}$ reconstituted inhibitor; Worthington Biochemical). Hippocampal tissue was then triturated with a fire-polished Pasteur pipette and resuspended in basal medium Eagle (Gibco) supplemented with $10 \%$ fetal bovine serum (v/v; Gibco), $0.45 \%$ glucose (w/v), 1 mm sodium pyruvate, $2 \mathrm{~mm}$ GlutaMax (Gibco), and $50 \mu \mathrm{g} / \mathrm{ml}$ penicillin/streptomycin (Gibco). Neurons were plated onto 24-well tissue culture dishes coated with poly-L-lysine at a cell density of $8-10 \times 10^{5}$ cells per well in neuronal medium. After $4 \mathrm{~h}$, the medium was replaced with serum-free Neurobasal A medium supplemented with B27 (Life Technologies). Cells were grown at $37^{\circ} \mathrm{C}$ in a humidified environment of $5 \% \mathrm{CO}_{2}$, and approximately half of the medium was exchanged every $3 \mathrm{~d}$. Chronic activity blockade was achieved using a medium supplemented with $1 \mu \mathrm{M}$ TTX and $150 \mu \mathrm{M}$ D-AP5 (Ascent Scientific) from day 6 in vitro. Neurons were transfected using Lipofectamine 2000 (Invitrogen), with shRNA against GSG1L or a scrambled control. Coexpression of GFP was used to identify transfected cells. After 45 min transfection, cells were washed with PBS, and the medium was replaced. Electrophysiological recordings were made $48-72 \mathrm{~h}$ later from pyramidal-shaped neurons. shRNA used to knockdown GSG1L and a nonsilencing scrambled control were selected from the Thermo Fisher Scientific Open Biosystems GIPZmir library (V3LHS_348573).

Quantification of GSG1L shRNA efficiency. HEK293 cells were transfected (as described above) with GSG1L and either GSG1L-shRNA or the scrambled control. After $2 \mathrm{~d}$, they were fixed for $10 \mathrm{~min}$ in a solution of $4 \%$ paraformaldehyde in PBS. Cells were washed three times in PBS and then blocked with $10 \%$ goat serum, $0.5 \%$ bovine serum albumin, and $0.2 \%$ Triton X-100 (all in PBS) for 10 min. Coverslips were incubated in blocking solution with GSG1L-specific antibody (rabbit, $0.5 \mu \mathrm{g} / \mathrm{ml}$; catalog \#121432; Abcam) for $60 \mathrm{~min}$, washed five times, and then incubated with an Alexa Fluor 647-conjugated goat rabbit-specific secondary antibody ( $4 \mu \mathrm{g} / \mathrm{ml}$; catalog \#A21244; Life Technologies) for an additional 45 min. After five additional washes, coverslips were mounted on slides using Prolong Gold antifade mounting medium (Invitrogen) and imaged using a confocal microscope (Leica) with a $40 \times$ oil-immersion objective. We identified isolated cells successfully transfected with shRNA or the scrambled control (expressing GFP) along with GSG1L (Alexa Fluor 647 fluorescence), and, for each cell, we recorded the corrected mean fluorescence intensity (minus background) of the somatic Alexa Fluor 647 signal. In cells that expressed shRNA, GSG1L protein was reduced by $72 \%$ compared with cells expressing the scrambled shRNA ( 25 and 57 cells, respectively, from two independent experiments). Note that this is likely an underestimation of the extent of knockdown, because the selection of HEK293 cells positive for both GSG1L and GFP excluded any cells in which GSG1L expression was eliminated completely by the shRNA.

Neuronal electrophysiology. Cells were viewed using upright or inverted microscopes (BX50WI or IX71; Olympus) and perfused at a rate of 2-3 $\mathrm{ml} / \mathrm{min}$ ( $2 \mathrm{ml}$ bath volume). The extracellular solution contained the following (in mM): $145 \mathrm{NaCl}, 2.5 \mathrm{KCl}, 2 \mathrm{CaCl}_{2}, 1 \mathrm{MgCl}_{2}, 10$ glucose, and 10 HEPES, adjusted to $\mathrm{pH} 7.3$ with $\mathrm{NaOH}$. To block voltage-gated sodium channels, NMDA and $\mathrm{GABA}_{\mathrm{A}}$ receptors, $0.5 \mu \mathrm{M}$ TTX, $20 \mu \mathrm{M}$ D-AP5, and $20 \mu \mathrm{M}$ SR-95531 [2-(3-carboxypropyl)-3-amino-6(4-methoxyphenyl)pyridazinium bromide] were included. For recordings from cultured hippocampal neurons, glycine receptors were blocked using $1 \mu \mathrm{M}$ strychnine (Ascent Scientific). Pipettes were filled with a solution containing the following (in $\mathrm{mm}$ ): $128 \mathrm{CsCl}, 10$ HEPES, 10 EGTA, 10 tetraethylammonium (TEA)-Cl, 2 MgATP, $1 \mathrm{CaCl}_{2}, 2 \mathrm{NaCl}, 1$ QX-314 [N-(2,6-dimethylphenylcarbamoylmethyl) triethylammonium bromide], and 0.1 spermine tetrahydrochloride (both from Tocris Bioscience), pH 7.4 with $\mathrm{CsOH}$ (final resistance of $\sim 4-8 \mathrm{M} \Omega$ ). Recordings were made using an Axopatch 200A amplifier, low-pass filtered at $5 \mathrm{kHz}$, and digitized at $20 \mathrm{kHz}$ using WINEDR software (John Dempster, University of Strathclyde). For cerebellar recordings, the internal solution contained the following (in mM): $140 \mathrm{CsCl}, 10$ HEPES, 5 EGTA, 2 MgATP, $0.5 \mathrm{CaCl}_{2}, 4 \mathrm{NaCl}$, and $0.1 \mathrm{~mm}$ spermine tetrahydrochloride, $\mathrm{pH}$ 7.4 with $\mathrm{CsOH}$. Recordings were made using an Axopatch 200B amplifier, low-pass filtered at $5 \mathrm{kHz}$, and digitized at $25-50 \mathrm{kHz}$ using Igor Pro (with NeuroMatic NClamp).

mEPSC analysis. We detected mEPSCs using amplitude threshold crossing, with the thresholds typically $\sim 10 \mathrm{pA}$ for cultured hippocampal neurons and $\sim 6 \mathrm{pA}$ for cultured cerebellar neurons. To calculate the RI of stellate cell mEPSCs, we used a method similar to that described previously (Bats et al., 2012). Because any mEPSCs carried predominantly by CP-AMPARs might fall below the detection threshold at positive potentials as a result of complete (or near-complete) block by intracellular spermine, simply comparing the amplitudes of detected events would lead to an underestimate of rectification. Accordingly, we calculated RI as follows:

$$
\mathrm{RI}=\frac{g_{\text {mean }+60} \times f_{+60}}{g_{\text {mean }-80} \times f_{-80}},
$$

where $g_{\text {mean }}$ is the peak conductance of the mean mEPSC at the given voltage, and $f$ is the frequency of the detected events. This is equivalent to the ratio of summed conductances for recordings of equal length, and, in the absence of rectification, RI would equal 1 . When analyzing mEPSC amplitudes, all events with a monotonic rise were included regardless of overlapping decays. For channel conductance (below) and kinetic analyses, only events that showed a monotonic rise and an uncontaminated decay were included. Such events were aligned on their rising phase before averaging. The decay of averaged mEPSCs was described by the sum of two exponentials, from which the weighted time constant of decay $\left(\tau_{\mathrm{w} \text {,decay }}\right)$ was calculated as the sum of the fast and slow time constants weighted by their fractional amplitudes. Peak-scaled NSFA (psNSFA) was used to estimate the weighted mean single-channel conductance of synaptic receptors (Traynelis et al., 1993). Each mEPSC was divided into 80 bins of equal amplitude, and the variance of the mEPSC about the scaled average in each bin was computed. The variance was plotted against the mean current, and the weighted mean single-channel current was estimated by fitting the full parabolic relationship with the following equation: 
a

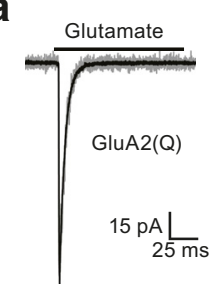

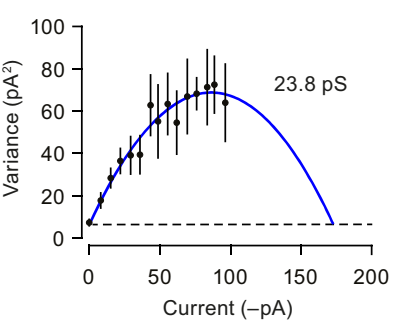

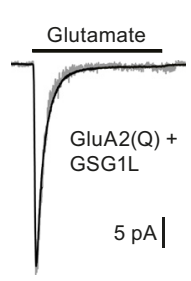

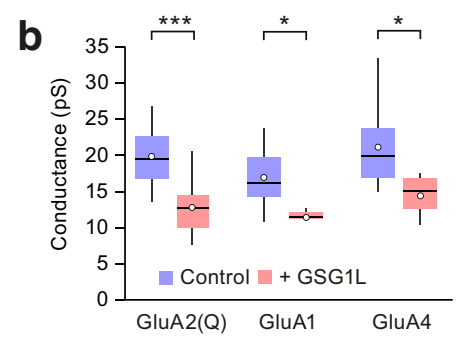
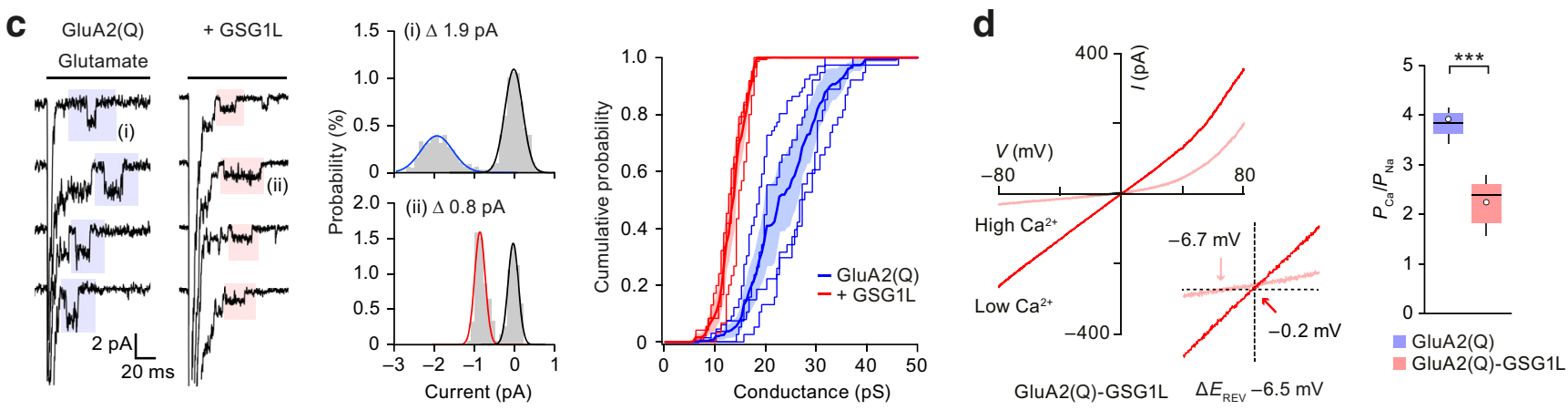

Figure 1. GSG1L attenuates single-channel conductance and calcium permeability of homomeric AMPARs. $\boldsymbol{a}$, Individual currents (gray) and averages (black) evoked by glutamate (10 mm, 100 $\mathrm{ms}$ ) applied to patches $(-60 \mathrm{mV}$ ) from cells expressing GluA2(Q), with and without GSG1L. Current-variance relationships show estimated weighted mean single-channel conductances for illustrated patches. Symbols show mean and error bars SEM. Dashed lines denote baseline variance. $\boldsymbol{b}$, Pooled data from NSFA. Box-and-whisker plots indicate median (line), 25 th to 75 th percentiles (box), range of data within $1.5 \times$ interquartile range of box (whiskers) and mean (open circles). ${ }^{*} p<0.05,{ }^{* * *} p<0.001$ (unpaired Welch two-sample $t$ tests, $n=7-14$ ). c, Resolved single-channel openings in the tail of macroscopic currents (truncated; $2 \mathrm{kHz}$ filter; left). All-point amplitude histograms from indicated individual channel events (middle). Cumulative probability distributions for conductances from four GluA2(Q) patches and three GluA2(Q)/GSG1L patches (right). Averaged distributions (bold lines) and SEM (fills). d, Representative I-V plots for GluA2(Q) GSG1L tandem constructs (voltage ramp in presence of $1 \mathrm{~mm}$ glutamate plus $50 \mu \mathrm{M}$ CTZ; no internal spermine) in low (1 mM) and high (30 mM) $\mathrm{Ca}^{2+}$. Enlargement shows reversal potential shift. Box-and-whisker plots (as in $\boldsymbol{b}$ ) show the effect of GSG1L on $P_{\mathrm{Ca}_{\mathrm{a}}} / P_{\mathrm{Na}}$ (*** $p<0.001$, Welch $t$ test, $n=7$ and 9 ).

$$
\sigma_{\mathrm{PS}}^{2}=\bar{i}-\bar{I}^{2} / N_{\mathrm{p}}+\sigma_{\mathrm{B}}^{2},
$$

where $\sigma_{\mathrm{PS}}^{2}$ is the peak-scaled variance, $\bar{I}$ is the mean current, $i$ is the weighted mean single-channel current, $N_{\mathrm{p}}$ is the number of channels open at the peak of the EPSC, and $\sigma_{\mathrm{B}}^{2}$ is the background variance.

Statistical analysis. Summary data are presented in the text as mean \pm SEM from $n$ cells. Comparisons involving two datasets only were performed using a two-sided Welch two-sample $t$ test that does not assume equal variance (normality was not tested statistically but judged from $Q-Q$ plots and/or density histograms). Analyses involving data from three or more groups were performed using two-way ANOVA (Welch heteroscedastic $F$ test), followed by pairwise comparisons using twosided Welch two-sample $t$ tests. For PhTx-433 concentration-response curves fit using a four-parameter logistic equation (sigmoidal dose response with variable slope), best-fit values for $\log \mathrm{EC}_{50}$ and maximum were compared using extra sum-of-squares $F$ tests. Exact $p$ values are presented to two decimal places, except when $p<0.0001$. Differences were considered significant at $p<0.05$. Statistical tests were performed using Prism version 6 (GraphPad Software) or R (version 3.1.2; the $\mathrm{R}$ Foundation for Statistical Computing; http://www.r-project.org/) and R Studio (version 0.98.1103; RStudio). No statistical test was used to predetermine sample sizes; these were based on standards of the field. No blinding or randomization was used.

\section{Results}

\section{GSG1L reduces mean single-channel conductance and} calcium permeability of CP-AMPARs

We initially examined the ability of GSG1L to regulate CPAMPARs by recording currents activated by fast application of glutamate to outside-out membrane patches from tsA201 cells expressing GluA2(Q), GluA1, or GluA4, together with GSG1L (Fig. 1a; see Materials and Methods). NSFA revealed that, in all cases, GSG1L reduced the weighted mean single-channel con- ductance of CP-AMPARs by 35\% (Fig. 1b). Two-way ANOVA showed a main effect of AMPAR subtype $\left(F_{(2,51)}=5.45, p=\right.$ $0.0072)$, a main effect of GSG1L $\left(F_{(1,51)}=34.21, p<0.0001\right)$, and no interaction $\left(F_{(2,51)}=0.20, p=0.82 ; n=7-14\right)$. Mean singlechannel conductance was reduced from $19.9 \pm 1.1$ to $13.1 \pm 1.3$ $\mathrm{pS}$ for GluA2(Q) $\left(n=14\right.$ and $\left.10 ; t_{(20.48)}=4.34, p=0.00030\right)$, from $16.9 \pm 1.7$ to $11.4 \pm 0.4 \mathrm{pS}$ for GluA1 $\left(n=7\right.$ and $8 ; t_{(6.74)}=$ $3.22, p=0.015)$, and from $21.2 \pm 2.0$ to $14.3 \pm 0.9 \mathrm{pS}$ for GluA4 (both $\left.n=9 ; t_{(11.15)}=3.09, p=0.010\right)$.

This reduction in the mean single-channel conductance estimated by NSFA was mirrored by a decrease in mean amplitude of directly resolved single-channel events in the tail of glutamate-evoked macroscopic currents (Fig. 1c). Mean channel conductance was reduced from $24.0 \pm 2.0$ to $13.7 \pm 0.7 \mathrm{pS}$ $\left(n=4\right.$ and 3 , respectively; $\left.t_{(3.63)}=4.87, p=0.010\right)$. Because recombinant AMPARs typically open to three or four closely spaced subconductance levels in the absence of auxiliary subunits (Swanson et al. 1997; Jin et al., 2003; Zhang et al., 2008; Prieto and Wollmuth, 2010), the effect of GSG1L could reflect an alteration in the relative probability of openings to these preexisting levels (Tomita et al. 2005). Alternatively, it may reflect a change in the absolute conductance levels (Shelley et al., 2012). We have not attempted to distinguish between these possibilities.

To determine the effect of GSG1L on relative $\mathrm{Ca}^{2+}$ permeability $\left(P_{\mathrm{Ca}} / P_{\mathrm{Na}}\right)$, we compared the reversal potentials of glutamateactivated currents in solutions containing low or high external $\mathrm{Ca}^{2+}$ ( 1 or $30 \mathrm{mm;} \mathrm{Fig.} \mathrm{1d).} \mathrm{Although} \mathrm{a} \mathrm{change} \mathrm{from} \mathrm{low} \mathrm{to} \mathrm{high} \mathrm{Ca}^{2+}$ had little effect on GluA2(Q) homomers, it shifted the reversal potential of GSG1L-containing receptors to more negative values. From the 
a
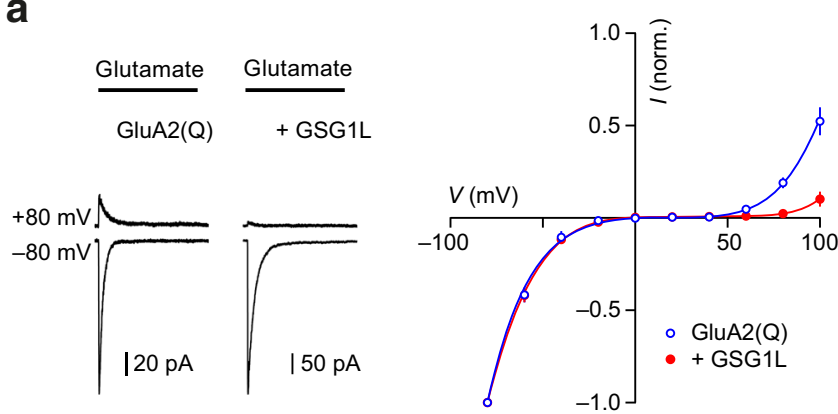

C

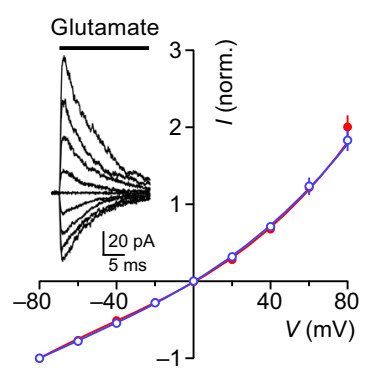

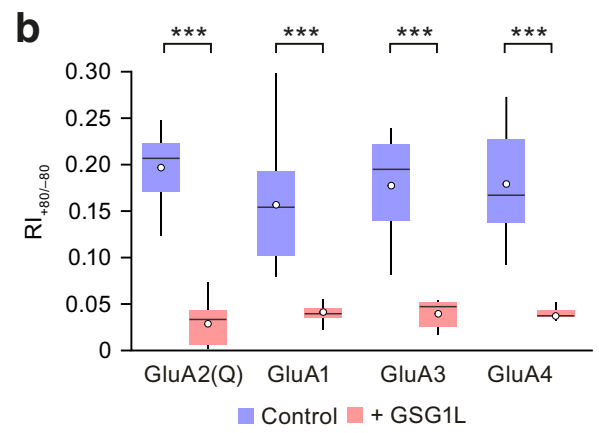

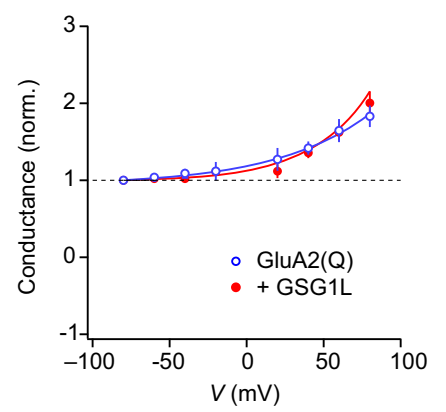

d

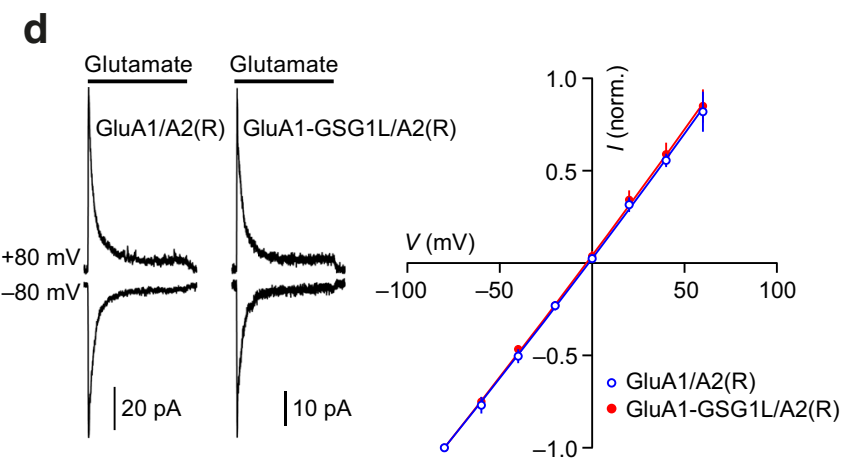

Figure 2. GSG1L enhances (P-AMPAR block by intracellular spermine. $\boldsymbol{a}$, Representative glutamate-evoked currents $(10 \mathrm{~mm}, 100 \mathrm{~ms})$ and normalized peak $/-V$ relationships $(\mathrm{global}$ average; $n=$ 6 and 8), showing increased rectification at positive potentials in the presence of GSG1L (100 $\mu \mathrm{m}$ spermine). Error bars denote SEM, and curves are weighted fits of seventh-order polynomials. $\boldsymbol{b}$, Box-and-whisker plots (as in Fig. 1) showing pooled RI data. ${ }^{* * *} p<0.001$ (unpaired Welch two-sample $t$ tests, $n=6-12$ ). c, Normalized $I-V$ relationships for homomeric GluA2(Q) receptors with and without GSG1L in the absence of spermine ( $n=5$ and 4, respectively; symbols as in $\boldsymbol{a}$ ). Vertical error bars denote SEM, and fitted lines are fourth-order polynomials. Inset shows a family of GluA2(Q)/GSG1L currents $(-80$ to $+80 \mathrm{mV}$ ) in response to application of $10 \mathrm{~mm}$ glutamate. Right, Normalized conductance against voltage for the data shown in the $I-V$ relationships. Fitted lines are drawn according to $G=G_{\min }+\left(G_{0}-G_{\min }\right) \exp \left(V_{\mathrm{m}} / V_{\mathrm{c}}\right)$, where $G_{0}$ is the conductance at $0 \mathrm{mV}$, $G_{\min }$ is the minimal conductance (normalized value of 1 ), and $V_{c}$ is a constant. Without $G S G 1 \mathrm{~L}, G_{0}$ was 1.11, and $V_{c}$ was $36.9 \mathrm{mV}$. With GSG1L, the corresponding values were 1.20 and $65.7 \mathrm{mV}$. $\boldsymbol{d}$, As in $\boldsymbol{a}$, but for heteromeric GluA1/GluA2(R) in absence and presence of GSG1L (as tandem). Note the unchanged near-linear peak $I-V$ relationship (third-order polynomial fits; $n=5$ and 3 ).

reversal potential shift, we estimated that GSG1L reduced $P_{\mathrm{Ca}} / P_{\mathrm{Na}}$ by $\sim 40 \%$ (from $3.9 \pm 0.2$ to $2.2 \pm 0.2 ; n=7$ and 9 , respectively; $t_{(12.83)}$ $=7.35, p<0.0001)$. These actions of GSG1L on mean channel conductance and relative calcium permeability contrast markedly with those of both TARPs and cornichons.

\section{GSG1L enhances spermine-dependent rectification of CP-AMPARs}

The voltage-dependent block by intracellular polyamines such as spermine, giving rise to inward rectification, has been used widely to identify the presence of synaptic CP-AMPARs (Liu and Cull-Candy, 2000; Noh et al., 2005; Bats et al., 2012). To determine whether, like TARPs (Soto et al., 2007), GSG1L reduces CP-AMPAR rectification, we constructed $I-V$ plots for currents obtained from outside-out patches in response to rapid application of glutamate. As expected, homomeric CP-AMPARs displayed inwardly rectifying $I-V$ plots in the presence of added intracellular spermine (100 $\mu \mathrm{M}$; Fig. $2 a)$. Strikingly, in the presence of GSG1L, the current at positive potentials was reduced, thus the rectification was enhanced rather than diminished (Fig. 2a,b). Two-way ANOVA showed no main effect of AMPAR subtype on the rectification index $\left(\mathrm{RI}_{+80 /-80} ; F_{(3,61)}=0.23, p=\right.$ $0.87)$, a main effect of GSG1L $\left(F_{(1,61)}=169.40, p<0.0001\right)$, and no interaction $\left(F_{(3,61)}=1.37, p=0.26 ; n=6-12\right)$. $\mathrm{RI}_{+80 /-80}$ was reduced from $0.21 \pm 0.01$ to $0.03 \pm 0.01$ for GluA2(Q) $(n=7$ and 9; $\left.t_{(11.25)}=10.37, p<0.0001\right)$, from $0.14 \pm 0.01$ to $0.04 \pm 0.01$ for GluA1 $\left(n=12\right.$ and $\left.11 ; t_{(11.72)}=6.17, p<0.0001\right)$, from $0.18 \pm 0.03$ to $0.05 \pm 0.01$ for GluA3 $\left(n=6\right.$ and $\left.7 ; t_{(5.75)}=5.23, p=0.0022\right)$, and from $0.18 \pm 0.03$ to $0.04 \pm 0.01$ for GluA4 $\left(n=6\right.$ and $10 ; t_{(5.19)}=$ $5.05, p=0.0036)$. a

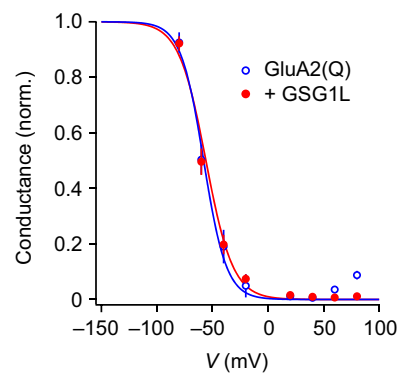

b

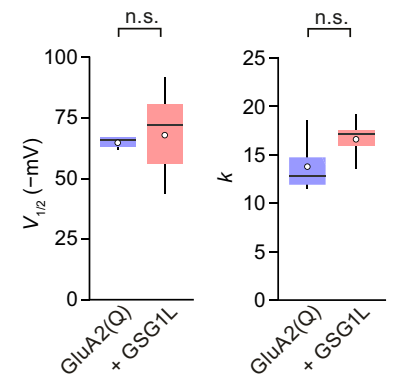

Figure 3. GSG1L does not shift voltage for half-maximal block of CP-AMPARs by intracellular spermine. $\boldsymbol{a}$, Plots of normalized conductance against voltage for the data shown in Figure $2 a$ (corrected for the outward rectification observed in the absence of spermine; Fig. $2 c$ ). Lines are fits at negative voltages to a Boltzmann function, $G=$ $G_{\max }\left(\frac{1}{1+\exp \left(V_{\mathrm{m}}-V_{1 / 2} / k\right)}\right)$, where $G_{\max }$ is the maximal glutamate-activated conductance at hyperpolarized voltages, $V_{1 / 2}$ is the voltage at which spermine block is halfmaximal, and $k$ is a slope factor describing the membrane potential shift necessary to cause an $e$-fold change in conductance. For the fits of the pooled data, the $V_{1 / 2}$ and slope values were similar with and without GSG1L: $-58.0 \mathrm{mV}$ and 10.3 for GluA2(Q); $-56.0 \mathrm{mV}$ and 12.2 for GluA2(Q)/GSG1L. $\boldsymbol{b}$, Boxand-whisker plots (as in Fig. 1) showing pooled $V_{1 / 2}$ and $k$ values from Boltzmann fits to $G-V$ plots for individual patches: $n=6 \mathrm{GluA2}(\mathrm{Q})$ and $9 \mathrm{GluA2}(\mathrm{Q}) / \mathrm{GSG} 1 \mathrm{~L}$ patches.

To decide whether the effect of GSG1L on rectification was mediated by a modulation of polyamine action rather than a change in the intrinsic properties of AMPAR gating, we examined the $I-V$ relationship of GluA2(Q), with and without GSG1L, in the absence 
of intracellular polyamines. Recordings were obtained a minimum of 15 min after patch excision to allow complete chelation of endogenous polyamines by the added $\mathrm{Na}_{2}$ ATP (see Materials and Methods). The control $I-V$ relationship and that obtained with GSG1L both showed clear outward rectification and were overlapping (Fig. 2c). This result suggests that the effect of GSG1L on inward rectification was entirely polyamine dependent.

Heteromeric GluA2(R)-containing AMPARs are unaffected by intracellular polyamines. Accordingly, GSG1L might be expected to have no effect on their normally linear $I-V$ relationship. To test this, we examined the effect of GSG1L on $\mathrm{Ca}^{2+}$ impermeable GluA1/GluA2(R) (Fig. 2d). In this case, we compared coexpressed GluA1 and GluA2(R) with coexpressed tandem GluA1-GSG1L and GluA2(R) (see Materials and Methods). Consistent with our results for CP-AMPARs, we found that $I-V$ plots from GluA2(R)-containing calciumimpermeable (CI)-AMPARs remained unchanged in the presence of GSG1L. Similar results were obtained with GluA4/ GluA2(R) receptors (data not shown).

Although GSG1L increased rectification as assessed using the measure of RI, we noted that the influence of GSG1L was apparent only at positive voltages. To examine this more closely, we next plotted conductance $(G)$ against voltage. As predicted from the overlap of the $I-V$ plots at negative voltages, Boltzmann fits to $G-V$ plots revealed that GSG1L produced no significant shift in the voltage for half-maximal block by spermine $\left[V_{1 / 2} ;-64.8 \pm 6.3 \mathrm{mV}\right.$ vs $-67.9 \pm 5.3 \mathrm{mV} ; n=6$ for GluA2(Q) and 9 for GluA2(Q)/GSG1L; $t_{(11.01)}=$ $-0.38, p=0.71]$ or in the slope factor $\left(k ; 13.8 \pm 1.1\right.$ vs $16.6 \pm 0.6 ; t_{(7.89)}=$ $-2.24, p=0.056$; Fig. 3$)$. This suggests that GSG1L primarily hinders the voltage-dependent relief of spermine block seen normally at positive potentials, which is thought to reflect permeation of the polyamine (Bowie and Mayer, 1995).

\section{PhTx-433 block of CP-AMPARs is attenuated by GSG1L}

Like polyamine-dependent inward rectification, the use-dependent block produced by extracellular application of the polyamine toxin PhTx-433 (Jackson et al., 2011) is generally considered a defining feature of CP-AMPARs (Liu and CullCandy, 2000; Noh et al., 2005; Bats et al., 2012; but see Bowie, 2012). Although the effects of this toxin on glutamate-activated CP-AMPAR-mediated currents are unaffected by TARPs (Jackson et al., 2011), we found that GSG1L attenuated PhTx-433

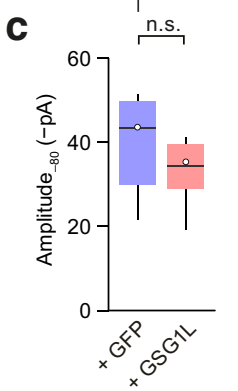
$n=7$ and 8 .

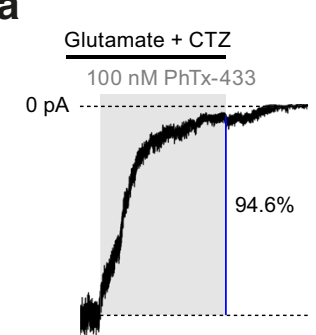

GluA4

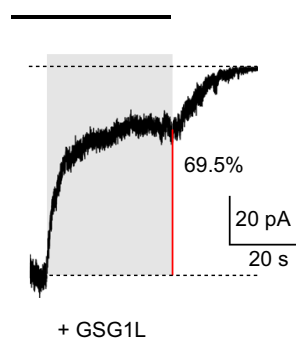

b

Figure 4. GSG1L reduces (P-AMPAR block by PhTx-433. $\boldsymbol{a}$, Representative glutamate-evoked patch currents $(-60 \mathrm{mV} ; 50 \mu \mathrm{M}$ (TZ) showing block after rapid jump into solution containing $100 \mathrm{~nm} \mathrm{PhTx-433} \mathrm{(0.2} \mathrm{kHz} \mathrm{filter,} \mathrm{for} \mathrm{display).} \mathrm{Steady-state} \mathrm{block}$ (denoted by vertical colored lines) produced by extracellular PhTx-433 (gray shading) is attenuated by GSG1L. $\boldsymbol{b}$, Concentrationresponse curves (mean \pm SEM; $n=3-7$ cells) show that GSG1L reduces $\mathrm{PhTx}-433$ potency $\left(\log \mathrm{EC}_{50}\right.$ ) and maximum block. Solid lines are fits to the Hill equation, giving the following values for GluA4 and GluA4 plus GSG1L: maximum block, 94.8 and $84.1 \%$; $\mathrm{EC}_{50}, 5.9 \mathrm{~nm}$ and $19.9 \mathrm{~nm}$; Hill slope, 1.2 and 1.2.
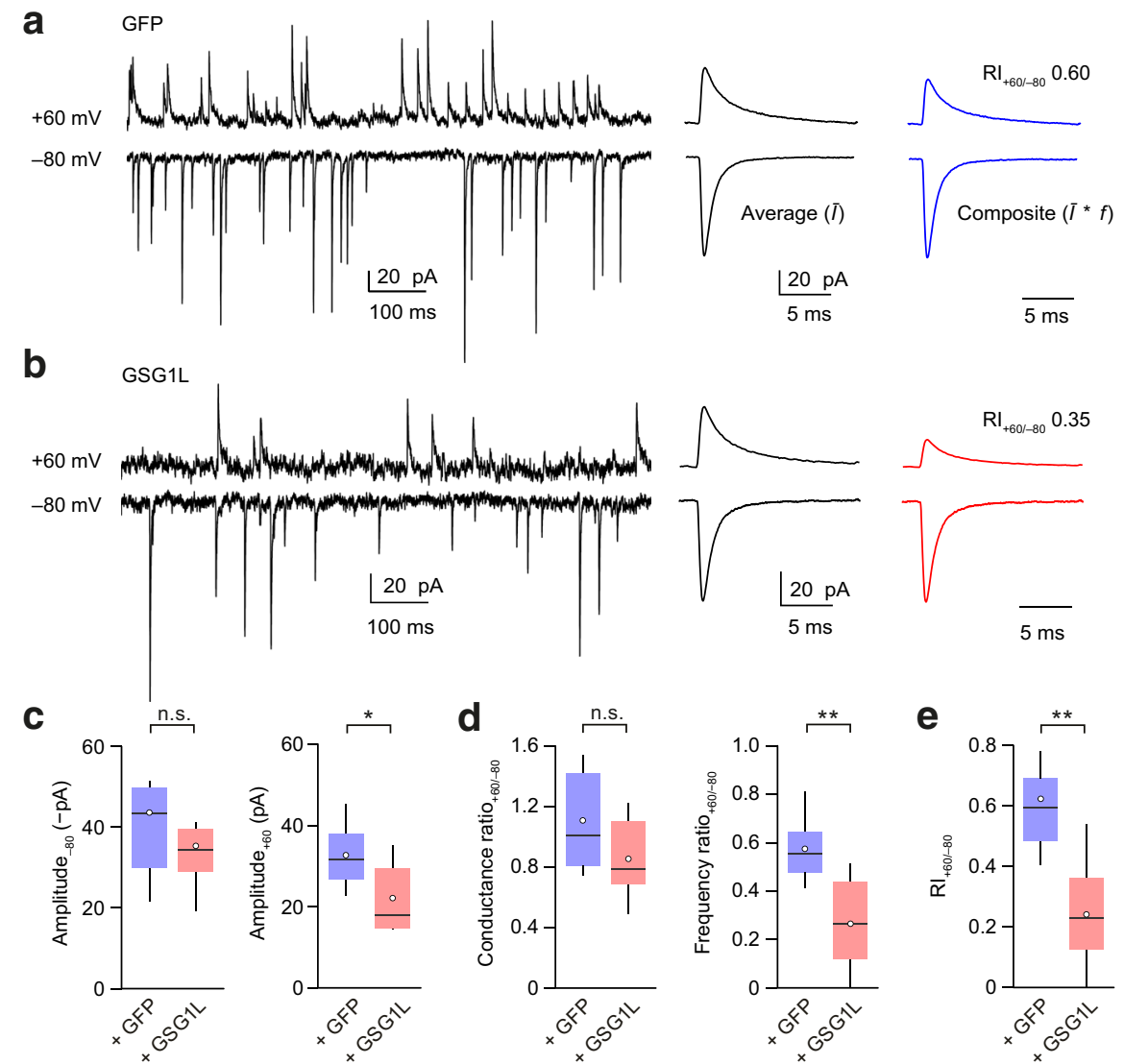

Figure 5. GSG1L expression alters mEPSC rectification in cultured cerebellar neurons. $\boldsymbol{a}$, Representative recordings of mEPSCs from a cultured stellate cell (control cell; GFP transfected) at -80 and $+60 \mathrm{mV}$. Traces are filtered at $2 \mathrm{kHz}$ for display. Middle, Averaged mEPSCs. Right, "Composite" mEPSCs showing the average waveforms scaled by the frequency of events at each voltage together with the value of $\mathrm{RI}_{+60 /-80}$ calculated as described in Materials and Methods. $\boldsymbol{b}$, As in $\boldsymbol{a}$, but for a representative GSG1L-transfected cell. c, Pooled data showing the peak mEPSC amplitudes at -80 and $+60 \mathrm{mV}$. $\boldsymbol{d}$, Pooled data showing the peak conductance ratios and frequency ratios at $-80 \mathrm{mV}$ and $+60 \mathrm{mV}$. e, Pooled data showing the increased rectification with GSG1L. Box-and-whisker plots as in Figure 1. ${ }^{*} p<0.05,{ }^{* *} p<0.01$, unpaired Welch $t$ test,

block of GluA4 CP-AMPARs (Fig. 4). Analysis of PhTX-433 concentration-response curves showed that GSG1L reduced both PhTx-433 potency $\left(\mathrm{EC}_{50}\right.$ reduced from 5.9 to $19.9 \mathrm{nM} ; F_{(1,31)}=$ 27.47, $p<0.0001$ ) and the maximum block (from 94.8 to $84.1 \% ; F_{(1,31)}=5.92, p=0.029$; extra sum-of-squares $F$ test). 
a

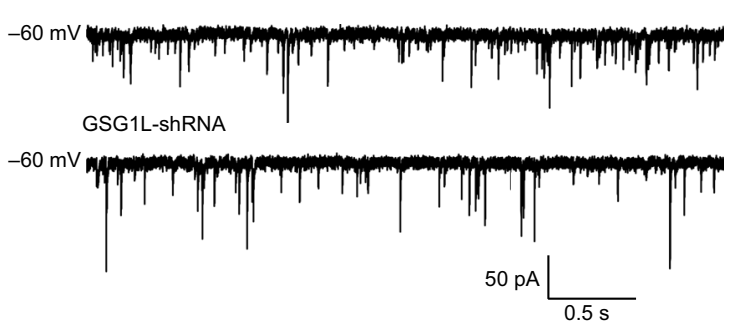

b

Scrambled shRNA GSG1L-shRNA

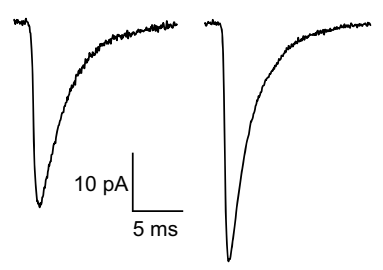

C

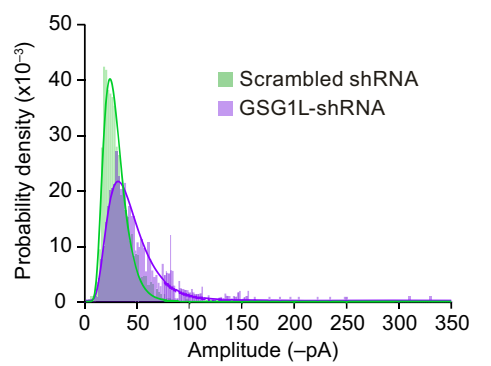

d

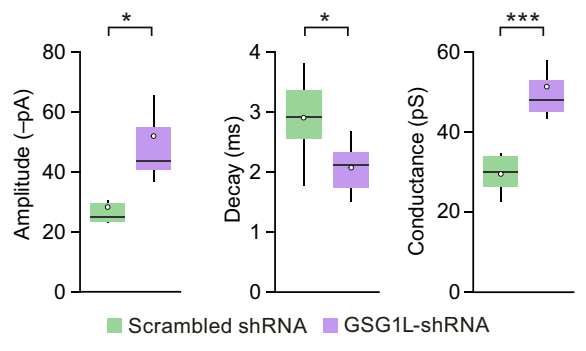

Figure 6. GSG1L knockdown alters properties of mEPSCs in cultured hippocampal neurons. $\boldsymbol{a}$, Representative recordings of mEPSCs from cultured hippocampal neurons $(-60 \mathrm{mV})$ treated with TTX and D-AP5 to promote the expression of synaptic (P-AMPARs (see Materials and Methods). Traces are from cells expressing scrambled shRNA or shRNA against GSG1L. $\boldsymbol{b}$, Averaged $\mathrm{mEPSC}$ from cells shown in $\boldsymbol{a}$. c, Averaged probability density histograms of mEPSC peak amplitude from six control cells (scrambled shRNA; 235-2011 mEPSCs per cell) and seven GSG1L-shRNA cells (66-1496 mEPSC s per cell). Solid lines are lognormal fits, with parameters $\mu$ and $\sigma$ being 0.36 and 3.31 for control and 0.46 and 3.67 for shRNA-GSG1L. $\boldsymbol{d}$, Pooled data showing the effect of GSG1L knockdown on mEPSC amplitude, mEPSC decay (weighted time constant $\tau_{\text {w,decay }}$ ), and synaptic channel conductance (from psNSFA). Box-and-whisker plots as in Figure 1. ${ }^{*} p<0.05,{ }^{* * *} p<0.001$, unpaired Welch $t$ test, $n=5-8$.

(data not shown). The failure of GSG1L to promote the expression of synaptic CPAMPARs in granule cells suggests that the increased rectification we observed in stellate cells, rather than reflecting an increased proportion of synaptic CP-AMPARs (or a decreased proportion of CI-AMPARs), likely reflects the reduced relief of spermine block at existing CP-AMPARs.

To establish the effects in neurons of endogenous GSG1L (Schwenk et al., 2012; Shanks et al., 2012), we next examined cultured hippocampal neurons treated with shRNA against GSG1L (see Materials and Methods; Fig. $6 a, b)$. Although a majority of the AMPARs in hippocampal CA1 pyramidal cells are thought to be calcium impermeable, the expression of CPAMPARs in these cells has been identified clearly (Rozov et al., 2012; Mattison et al., 2014). Furthermore, CP-AMPAR expression is known to increase in cultured hippocampal pyramidal neurons after blockade of synaptic activity (Ju et al., 2004). Therefore, to increase the prevalence of CP-AMPARs in our cells, we maintained them in a condition of reduced activity ( $1 \mu \mathrm{M}$ TTX, $150 \mu \mathrm{M}$ D-AP5) and confirmed the presence of inwardly rectifying mEPSCs (data not shown). In pyramidal-shaped cells, knockdown of

GSG1L modifies the properties of neuronal CP-AMPARs We next examined whether GSG1L could similarly modulate synaptic CP-AMPARs. Cerebellar stellate cells are known to express a mixture of CI- and CP-AMPARs (Liu and Cull-Candy, 2000). These cells express TARPs (Fukaya et al., 2005) but conveniently lack GSG1L (Lein et al., 2007), allowing us to examine the effect of GSG1L on native AMPARs. We recorded mEPSCs at -80 and $+60 \mathrm{mV}$ from cultured stellate cells transfected with GFP (control) or GSG1L (Fig. 5a,b). In our culture conditions, mEPSCs from control cells showed moderate inward rectification, consistent with the presence of CP-AMPARs. Transfection with GSG1L had no effect on mEPSC amplitude at $-80 \mathrm{mV}$ $(-43.6 \pm 7.7 \mathrm{vs}-35.5 \pm 4.3 \mathrm{pA}, n=7$ and 8 for GFP and GSG1L transfected cells, respectively; $\left.t_{(9.52)}=0.94, p=0.37\right)$ but reduced the average amplitude at $+60 \mathrm{mV}$ (from $32.7 \pm 3.3$ to $22.1 \pm 3.2$ $\mathrm{pA} ; t_{(9.52)}=0.94, p=0.037$; Fig. $5 c$ ). However, because the AMPAR number and subtype may vary from one synapse to another within an individual cell, those mEPSCs carried primarily by CP-AMPARs might be undetectable at positive potentials because of complete (or near-complete) block by intracellular spermine. Thus, both the amplitude and frequency of mEPSCs at $+60 \mathrm{mV}$ could be affected by spermine such that a simple comparison of the amplitudes of the detected events would lead to an underestimate of rectification. In GSG1L-transfected cells, although the ratio of mEPSC peak conductances $(+60 /-80 \mathrm{mV})$ was not reduced significantly $\left(t_{(11.14)}=1.60, p=0.14\right)$, the ratio of frequencies was changed $\left(t_{(12.60)}=3.65, p=0.0031\right.$; Fig. $\left.5 d\right)$. Accordingly, $\mathrm{RI}_{+60 /-80}$ (see Materials and Methods) was reduced from $0.62 \pm 0.08$ to $0.24 \pm 0.07\left(n=7\right.$ and $8 ; t_{(12.13)}=3.69, P=$ 0.0031; Fig. $5 e$ ). Of note, when we transfected GSG1L into cerebellar granule cells, in which synaptic currents are mediated solely by CI-AMPARs, mEPSC frequency, amplitude, and RI was unchanged
GSG1L led to an acceleration of mEPSC decay, from $2.9 \pm 0.3$ to $2.1 \pm 0.1 \mathrm{~ms}$ (Fig. 6b,d). Because the deactivation of recombinant GluA1/GluA2(R) receptors is known to be prolonged in the presence of GSG1L (Schwenk et al., 2012), this could reflect an effect on CI-AMPARs, or CP-AMPARs, or both.

GSG1L knockdown also resulted in an increase in mEPSC amplitude (Fig. 6b), which was accompanied by a broadening of the amplitude distribution, suggesting a heterogeneity across synapses (Fig. 6c). On average, mEPSC amplitude was increased by $\sim 80 \%$, from $-28.3 \pm 3.2$ to $-52.0 \pm 7.6 \mathrm{pA}$ ( $n=6$ and 7 ; $t_{(7.98)}=-2.89, p=0.020$; Fig. $\left.6 d\right)$. This was accompanied by a proportional increase in the mean synaptic single-channel conductance estimated from psNSFA (see Materials and Methods) from $29.6 \pm 5.1$ to $51.4 \pm 3.5 \mathrm{pS}\left(n=5\right.$ and $8 ; t_{(10.80)}=-5.24$, $p=0.0012$; Fig. $6 d$ ). The estimated number of channels activated during a quantal event was not changed after GSG1L knockdown ( $34 \pm 4$ vs $30 \pm 5$ ), consistent with the view that the increased mEPSC amplitude reflected an increase in mean single-channel conductance associated with loss of GSG1L. The combined effects of GSG1L knockdown could reflect changes in both CI- and CP-AMPAR properties. However, in studies of recombinant receptors, we found GSG1L to have no effect of the mean channel conductance of heteromeric, GluA1-GSG1L/GluA2(R) CIAMPARs $\left(n=6\right.$ and $\left.7 ; t_{(9.95)}=-0.26, p=0.79\right)$. This contrasts with the effect of GSG1L on the mean channel conductance of homomeric CP-AMPARs (Fig. 1b) and suggests that synaptic CP-AMPARs are altered after GSG1L knockdown.

\section{Discussion}

In this study, we report novel features of AMPAR modulation by GSG1L. Our focus was on CP-AMPARs. We found that GSG1L 
suppressed recombinant CP-AMPAR function by decreasing average single-channel conductance, decreasing calcium permeability, and inhibiting the normal voltage-dependent relief of intracellular polyamine block that occurs at positive potentials. Outward current flow was thus greatly diminished. Although GSG1L has been shown previously to slow deactivation and desensitization of CP-AMPARs (Shanks et al., 2012) in a manner similar to that of both type 1 TARPs $(\gamma-2, \gamma-3, \gamma-4$, and $\gamma-8)$ and cornichons (CNIH2/3), its combined effects differ fundamentally from those seen with these canonical AMPAR auxiliary subunits. Importantly, the influence of GSG1L on CP-AMPAR channel conductance and calcium permeability are opposite to those of both TARPs and cornichons. Furthermore, its effects on polyamine block appear unconventional. With TARPed AMPARs, in the presence of intracellular polyamines, outward current is detected at approximately $+30 \mathrm{mV}$ (Soto et al., 2007), likely reflecting polyamine permeation and relief of block (Bowie et al., 1998). In contrast, in the presence of GSG1L, outward current is greatly decreased even at very depolarized potentials, implying that polyamine permeation is inhibited. Conversely, block at negative voltages appears unaffected. Overall, our study suggests that auxiliary subunits can act to suppress and enhance current flow through AMPARs.

Consistent with our data on recombinant AMPARs, we find that overexpression of GSG1L in cerebellar interneurons that express synaptic CP-AMPARs results in an increase in mEPSC rectification. Moreover, we find that knockdown of GSG1L in cultured hippocampal neurons increases the peak amplitude of mEPSCs and enhances the conductance of the underlying channels, suggesting that, in these cells, GSG1L regulates the properties of synaptic AMPARs. Although it is possible that the influence of GSG1L on CP-AMPARs may vary in other brain areas, because of its presence together with different subsets of auxiliary subunits (Schwenk et al., 2014), this finding emphasizes the contrast with canonical auxiliary subunits, the genetic disruption of which typically results in a reduction of AMPAR expression and activity (Hashimoto et al., 1999; Rouach et al., 2005; Fukaya et al., 2006; Bats et al., 2012). It will be interesting to determine whether suppressive effects of GSG1L on native CP-AMPARs involve direct modulation of channel function or whether its effects are indirect and result from negation of the actions of other auxiliary subunits. The fact that we observed clear suppressive effects of GSG1L with heterologously expressed CP-AMPARs in the absence of TARPs or CNIHs indicates that a direct effect can occur.

An additional difference between GSG1L and other auxiliary subunits is seen in its effects on extracellular block by the polyamine toxin PhTx-433 (Jackson et al., 2011). This toxin has been used widely to identify the presence of neuronal CP-AMPARs (Isaac et al., 2007). Whereas the blocking action of PhTx-433 on glutamate-gated currents is unaffected by TARPs $\gamma$-2 or $\gamma-8$ (Jackson et al., 2011), its ability to block, and hence identify, CP-AMPARs is diminished by GSG1L. This observation raises the intriguing question as to whether the presence of an auxiliary subunit with GSG1L-like properties could account for reports of CP-AMPARs in cortical oligodendrocyte lineage cells and retinal amacrine cells that exhibit a relatively low sensitivity to block by polyamine toxins (Meucci et al., 1996; Osswald et al., 2007; Diamond, 2011).

Calcium entry via CP-AMPARs has been implicated in the induction of synaptic plasticity (Gu et al., 1996; Mahanty and Sah, 1998; Laezza et al., 1999; Liu and Cull-Candy, 2000) and neuronal damage (Carriedo et al., 1998; Noh et al., 2005). Moreover, the interaction of intracellular polyamines with CP-AMPARs contributes to short-term plasticity (Rozov and Burnashev, 1999; Shin et al., 2005). Here we show that GSG1L attenuates the calcium permeability and increases intracellular polyamine block of CP-AMPARs. These effects, together with the marked slowing of recovery from desensitization of homomeric CP-AMPARs (Shanks et al., 2012), highlight the potential importance of regulated GSG1L expression. Specifically, the regulation of its expression could provide a mechanism for the dynamic control of CP-AMPAR function at a cellular level. In this context, GSG1L could mitigate damaging CP-AMPAR-mediated calcium entry in certain pathological conditions.

\section{References}

Bats C, Soto D, Studniarczyk D, Farrant M, Cull-Candy SG (2012) Channel properties reveal differential expression of TARPed and TARPless AMPARs in stargazer neurons. Nat Neurosci 15:853-861. CrossRef Medline

Beaudoin GM 3rd, Lee SH, Singh D, Yuan Y, Ng YG, Reichardt LF, Arikkath J (2012) Culturing pyramidal neurons from the early postnatal mouse hippocampus and cortex. Nat Protoc 7:1741-1754. CrossRef Medline

Bellone C, Lüscher C (2012) Drug-evoked plasticity: do addictive drugs reopen a critical period of postnatal synaptic development? Front Mol Neurosci 5:75. CrossRef Medline

Bowie D (2012) Redefining the classification of AMPA-selective ionotropic glutamate receptors. J Physiol 590:49-61. CrossRef Medline

Bowie D, Mayer ML (1995) Inward rectification of both AMPA and kainate subtype glutamate receptors generated by polyamine-mediated ion channel block. Neuron 15:453-462. CrossRef Medline

Bowie D, Lange GD, Mayer ML (1998) Activity-dependent modulation of glutamate receptors by polyamines. J Neurosci 18:8175-8185. Medline

Carriedo SG, Yin HZ, Sensi SL, Weiss JH (1998) Rapid $\mathrm{Ca}^{2+}$ entry through $\mathrm{Ca}^{2+}$-permeable AMPA/Kainate channels triggers marked intracellular $\mathrm{Ca}^{2+}$ rises and consequent oxygen radical production. J Neurosci 18: 7727-7738. Medline

Clem RL, Huganir RL (2010) Calcium-permeable AMPA receptor dynamics mediate fear memory erasure. Science 330:1108-1112. CrossRef Medline

Constals A, Penn AC, Compans B, Toulmé E, Phillipat A, Marais S, Retailleau N, Hafner AS, Coussen F, Hosy E, Choquet D (2015) Glutamateinduced AMPA receptor desensitization increases their mobility and modulates short-term plasticity through unbinding from Stargazin. Neuron 85:787-803. CrossRef Medline

Coombs ID, Soto D, Zonouzi M, Renzi M, Shelley C, Farrant M, Cull-Candy SG (2012) Cornichons modify channel properties of recombinant and glial AMPA receptors. J Neurosci 32:9796-9804. CrossRef Medline

Cull-Candy S, Kelly L, Farrant M (2006) Regulation of $\mathrm{Ca}^{2+}$-permeable AMPA receptors: synaptic plasticity and beyond. Curr Opin Neurobiol 16:288-297. CrossRef Medline

Diamond JS (2011) Calcium-permeable AMPA receptors in the retina. Front Mol Neurosci 4:27. CrossRef Medline

Fukaya M, Yamazaki M, Sakimura K, Watanabe M (2005) Spatial diversity in gene expression for VDCCgamma subunit family in developing and adult mouse brains. Neurosci Res 53:376-383. CrossRef Medline

Fukaya M, Tsujita M, Yamazaki M, Kushiya E, Abe M, Akashi K, Natsume R, Kano M, Kamiya H, Watanabe M, Sakimura K (2006) Abundant distribution of TARP gamma-8 in synaptic and extrasynaptic surface of hippocampal neurons and its major role in AMPA receptor expression on spines and dendrites. Eur J Neurosci 24:2177-2190. CrossRef Medline

Geiger JR, Melcher T, Koh DS, Sakmann B, Seeburg PH, Jonas P, Monyer H (1995) Relative abundance of subunit mRNAs determines gating and $\mathrm{Ca}^{2+}$ permeability of AMPA receptors in principal neurons and interneurons in rat CNS. Neuron 15:193-204. CrossRef Medline

Gu JG, Albuquerque C, Lee CJ, MacDermott AB (1996) Synaptic strengthening through activation of $\mathrm{Ca}^{2+}$-permeable AMPA receptors. Nature 381:793-796. CrossRef Medline

Haering SC, Tapken D, Pahl S, Hollmann M (2014) Auxiliary subunits: 
shepherding AMPA receptors to the plasma membrane. Membranes 4:469-490. CrossRef Medline

Hashimoto K, Fukaya M, Qiao X, Sakimura K, Watanabe M, Kano M (1999) Impairment of AMPA receptor function in cerebellar granule cells of ataxic mutant mouse Stargazer. J Neurosci 19:6027-6036. Medline

Isaac JT, Ashby MC, McBain CJ (2007) The role of the GluR2 subunit in AMPA receptor function and synaptic plasticity. Neuron 54:859-871. CrossRef Medline

Jackson AC, Nicoll RA (2011) The expanding social network of ionotropic glutamate receptors: TARPs and other transmembrane auxiliary subunits. Neuron 70:178-199. CrossRef Medline

Jackson AC, Milstein AD, Soto D, Farrant M, Cull-Candy SG, Nicoll RA (2011) Probing TARP modulation of AMPA receptor conductance with polyamine toxins. J Neurosci 31:7511-7520. CrossRef Medline

Jin R, Banke TG, Mayer ML, Traynelis SF, Gouaux E (2003) Structural basis for partial agonist action at ionotropic glutamate receptors. Nat Neurosci 6:803-810. CrossRef Medline

Ju W, Morishita W, Tsui J, Gaietta G, Deerinck TJ, Adams SR, Garner CC, Tsien RY, Ellisman MH, Malenka RC (2004) Activity-dependent regulation of dendritic synthesis and trafficking of AMPA receptors. Nat Neurosci 7:244-253. CrossRef Medline

Kessels HW, Malinow R (2009) Synaptic AMPA receptor plasticity and behavior. Neuron 61:340-350. CrossRef Medline

Kott S, Sager C, Tapken D, Werner M, Hollmann M (2009) Comparative analysis of the pharmacology of GluR1 in complex with transmembrane AMPA receptor regulatory proteins gamma2, gamma3, gamma4, and gamma8. Neuroscience 158:78-88. CrossRef Medline

Laezza F, Doherty JJ, Dingledine R (1999) Long-term depression in hippocampal interneurons: joint requirement for pre- and postsynaptic events. Science 285:1411-1414. CrossRef Medline

Lein ES, Hawrylycz MJ, Ao N, Ayres M, Bensinger A, Bernard A, Boe AF, Boguski MS, Brockway KS, Byrnes EJ, Chen L, Chen L, Chen TM, Chin MC, Chong J, Crook BE, Czaplinska A, Dang CN, Datta S, Dee NR, et al. (2007) Genome-wide atlas of gene expression in the adult mouse brain. Nature 445:168-176. CrossRef Medline

Liu SJ, Zukin RS (2007) $\mathrm{Ca}^{2+}$-permeable AMPA receptors in synaptic plasticity and neuronal death. Trends Neurosci 30:126-134. CrossRef Medline

Liu SQ, Cull-Candy SG (2000) Synaptic activity at calcium-permeable AMPA receptors induces a switch in receptor subtype. Nature 405:454458. CrossRef Medline

Mahanty NK, Sah P (1998) Calcium-permeable AMPA receptors mediate long-term potentiation in interneurons in the amygdala. Nature 394:683687. CrossRef Medline

Mattison HA, Bagal AA, Mohammadi M, Pulimood NS, Reich CG, Alger BE, Kao JP, Thompson SM (2014) Evidence of calcium-permeable AMPA receptors in dendritic spines of CA1 pyramidal neurons. J Neurophysiol 112:263-275. CrossRef Medline

Meucci O, Fatatis A, Holzwarth JA, Miller RJ (1996) Developmental regulation of the toxin sensitivity of $\mathrm{Ca}^{2+}$-permeable AMPA receptors in cortical glia. J Neurosci 16:519-530. Medline

Newpher TM, Ehlers MD (2008) Glutamate receptor dynamics in dendritic microdomains. Neuron 58:472-497. CrossRef Medline

Noh KM, Yokota H, Mashiko T, Castillo PE, Zukin RS, Bennett MV (2005) Blockade of calcium-permeable AMPA receptors protects hippocampal neurons against global ischemia-induced death. Proc Natl Acad Sci U S A 102:12230-12235. CrossRef Medline

Osswald IK, Galan A, Bowie D (2007) Light triggers expression of philanthotoxin-insensitive $\mathrm{Ca}^{2+}$-permeable AMPA receptors in the developing rat retina. J Physiol 582:95-111. CrossRef Medline

Prieto ML, Wollmuth LP (2010) Gating modes in AMPA receptors. J Neurosci 30:4449-4459. CrossRef Medline

Rouach N, Byrd K, Petralia RS, Elias GM, Adesnik H, Tomita S, Karimzade- gan S, Kealey C, Bredt DS, Nicoll RA (2005) TARP gamma-8 controls hippocampal AMPA receptor number, distribution and synaptic plasticity. Nat Neurosci 8:1525-1533. CrossRef Medline

Rozov A, Burnashev N (1999) Polyamine-dependent facilitation of postsynaptic AMPA receptors counteracts paired-pulse depression. Nature 401:594-598. CrossRef Medline

Rozov A, Sprengel R, Seeburg PH (2012) GluA2-lacking AMPA receptors in hippocampal CA1 cell synapses: evidence from gene-targeted mice. Front Mol Neurosci 5:22. CrossRef Medline

Schwenk J, Harmel N, Brechet A, Zolles G, Berkefeld H, Müller CS, Bildl W, Baehrens D, Hüber B, Kulik A, Klöcker N, Schulte U, Fakler B (2012) High-resolution proteomics unravel architecture and molecular diversity of native AMPA receptor complexes. Neuron 74:621-633. CrossRef Medline

Schwenk J, Baehrens D, Haupt A, Bildl W, Boudkkazi S, Roeper J, Fakler B, Schulte U (2014) Regional diversity and developmental dynamics of the AMPA-receptor proteome in the mammalian brain. Neuron 84:41-54. CrossRef Medline

Shanks NF, Savas JN, Maruo T, Cais O, Hirao A, Oe S, Ghosh A, Noda Y, Greger IH, Yates JR 3rd, Nakagawa T (2012) Differences in AMPA and kainate receptor interactomes facilitate identification of AMPA receptor auxiliary subunit GSG1L. Cell Rep 1:590-598. CrossRef Medline

Shelley C, Farrant M, Cull-Candy SG (2012) TARP-associated AMPA receptors display an increased maximum channel conductance and multiple kinetically distinct open states. J Physiol 590:5723-5738. CrossRef Medline

Shin J, Shen F, Huguenard JR (2005) Polyamines modulate AMPA receptor-dependent synaptic responses in immature layer $\mathrm{v}$ pyramidal neurons. J Neurophysiol 93:2634-2643. CrossRef Medline

Soto D, Coombs ID, Kelly L, Farrant M, Cull-Candy SG (2007) Stargazin attenuates intracellular polyamine block of calcium-permeable AMPA receptors. Nat Neurosci 10:1260-1267. CrossRef Medline

Soto D, Coombs ID, Renzi M, Zonouzi M, Farrant M, Cull-Candy SG (2009) Selective regulation of long-form calcium-permeable AMPA receptors by an atypical TARP, gamma-5. Nat Neurosci 12:277-285. CrossRef Medline

Soto D, Coombs ID, Gratacòs-Batlle E, Farrant M, Cull-Candy SG (2014) Molecular mechanisms contributing to TARP regulation of channel conductance and polyamine block of calcium-permeable AMPA receptors. J Neurosci 34:11673-11683. CrossRef Medline

Swanson GT, Kamboj SK, Cull-Candy SG (1997) Single-channel properties of recombinant AMPA receptors depend on RNA editing, splice variation, and subunit composition. J Neurosci 17:58-69. Medline

Szabo A, Somogyi J, Cauli B, Lambolez B, Somogyi P, Lamsa KP (2012) Calcium-permeable AMPA receptors provide a common mechanism for LTP in glutamatergic synapses of distinct hippocampal interneuron types. J Neurosci 32:6511-6516. CrossRef Medline

Tomita S, Adesnik H, Sekiguchi M, Zhang W, Wada K, Howe JR, Nicoll RA, Bredt DS (2005) Stargazin modulates AMPA receptor gating and trafficking by distinct domains. Nature 435:1052-1058. CrossRef Medline

Traynelis SF, Silver RA, Cull-Candy SG (1993) Estimated conductance of glutamate receptor channels activated during EPSCs at the cerebellar mossy fiber-granule cell synapse. Neuron 11:279-289. CrossRef Medline

Traynelis SF, Wollmuth LP, McBain CJ, Menniti FS, Vance KM, Ogden KK, Hansen KB, Yuan H, Myers SJ, Dingledine R (2010) Glutamate receptor ion channels: structure, regulation, and function. Pharmacol Rev 62:405496. CrossRef Medline

Watanabe S, Kusama-Eguchi K, Kobayashi H, Igarashi K (1991) Estimation of polyamine binding to macromolecules and ATP in bovine lymphocytes and rat liver. J Biol Chem 266:20803-20809. Medline

Zhang W, Cho Y, Lolis E, Howe JR (2008) Structural and single-channel results indicate that the rates of ligand binding domain closing and opening directly impact AMPA receptor gating. J Neurosci 28:932-943. CrossRef Medline 